\title{
Analyzing Physical Education Teachers' Behaviors on Supporting Learner's Autonomy and Leadership Styles
}

\section{Beden Eğitimi Öğretmenlerinin Öğrenen Özerkliğini Destekleme Davranışları ve Liderlik Stillerinin Çeşitli Değişkenler Açısından İncelenmesi}

\author{
Sunacan Ilke Bal ${ }^{1}$ \\ Faculty of Sport Sciences, \\ (D) https://orcid.org/0000-0002-1807-5508
University of Mersin, Mersin, Turkey
}

Zekai Pehlevan (iD) https://orcid.org/0000-0003-4532-2508

Faculty of Sport Sciences, University of Mersin, Mersin, Turkey

Received: October 26, 2019 DOI:10.30655/besad.2020.24
Accepted: March 15, 2020

https//:doi.org/10.30655/besad.2020.24
Online Published: March 31, 2020

\begin{abstract}
The general aim of the study is to examine the behaviors of secondary and high school physical education teachers in teacher leadership styles and behaviors to support learner autonomy according to gender, school type, professional working year and class sizes. The sample of the study consists of 132 physical education teachers working in secondary and high schools in Mersin with the easily accessible sampling method. $41.7 \%$ of the physical education teachers participating in the study were female $(n=55)$ and $58.3 \%$ were male $(n=77) .70 .5 \%$ of the participants were working in secondary school $(n=93)$ and $29.5 \%$ in high school $(n=39)$. The duration of service of physical education teachers participating in the study ranged between 01-34 years. Class sizes of teachers were grouped as 20-25, 26-35 and 36. "Teacher Leadership Styles Scale" and "Learner Autonomy Support Scale" were used as data collection tools in this study. Descriptive statistics, $t$-test, Kruskal Wallis $H$ test and Pearson correlation coefficient were used to analyze the data. The margin of error was taken as 0.05. According to the analysis results; it was concluded that physical education teachers displayed semi-democratic leadership style ( $M=69.79, S D=3.32$ ). Teachers' levels of perceiving learner autonomy support behaviors are necessary $(M=1.19, S D=0.55)$ lower than the display levels $(M=2.20, S D=0.55)$. Among the sub-dimensions of autonomy support, physical education teachers considered that evaluation process support was the most necessary $(M=1.94, S D=0.72)$ and displayed $(M=2.34, S D=$ 0.73). In addition, teachers' gender It (132) $=0.61 ; p>.05$ I, to school levels It (132) $=0.41 ; p>05$ ] and there was no
\end{abstract}

\footnotetext{
${ }^{1}$ Corresponding author: Sunacan ilke Bal

Mersin Üniversitesi, Spor Bilimleri Fakültesi, Çiftlikköy Yerleşkesi, Yenişehir, Mersin

s.likedemirci@hotmail.com
} 
significant difference between leadership styles according to the class sizes $\left(X^{2}=1.16, d f=2 p>.05\right)$; gender I $t_{\text {Necessity }}$ $(132)=-0.99, p>05 ; t_{\text {Display }}(132)=-1.55, p>.05$ l, school level $\left.t_{\text {Necessity }}(132)=-0.22, p>05 ; t_{\text {Display }}(132)=-1.37, p>.05\right]$ and according to the class sizes $\left(X_{\text {Necessity }}^{2}=4.01, d f=2 p>.05: X_{\text {Display }}^{2}=2.98, d f=2 p>.05\right)$ also significant learner autonomy support behaviors did not find a difference. There is a significant negative correlation between physical education teachers' leadership styles and learner autonomy support behaviors, while there is a positive correlation between professional working years and learner autonomy support behaviors ( $p<.05)$. According to the results of the research, it was determined that physical education teachers had a semi-democratic leadership style and there was no consistency between the necessity and display of learner autonomy.

Keywords: Learner autonomy, leadership style, physical education teacher

\section{Öz}

Araştırmanın genel amacl, ortaokul ve lise beden eğitimi öğretmenlerinin, öğretmen liderlik stilleri ile ögrenen özerkliğini destekleme davranışlarını cinsiyet, okul türü, mesleki çalışma yılı ve sınıf mevcut grupları değişkenlerine göre incelemektir. Araştırmanın örneklemini kolay ulaşılabilir örnekleme yöntemi ile Mersin ilinde ortaokul ve lisede görev yapan 132 beden eğitimi ögrretmeni oluşturmaktadır. Araştırmaya katılan beden eğitimi ögretmenlerinin \% 41.7'si kadın ( $n=55)$, \% 58.3'ü erkektir ( $n=77)$. Katılımciların \% 70.5'i ortaokulda ( $n=93)$ ve \% 29.5'i lisede ( $n=39$ ) görev yapmaktadır. Araştırmaya katılan beden eğitimi öğretmenlerin hizmet süreleri 01-34 yıl arasında değişmektedir. Öğretmenlerin sınıf mevcutları 20-25, 26-35 ve 36 üstü olarak gruplandırılmıştır. Araştırmada veri toplama aracı olarak "Öğretmen Liderlik Stilleri Ölçeği" ve "Öğrenen Özerkliğini Destekleme Ölçeği" kullanılmıştır. Araştırma verilerinin çözümlenmesinde betimsel istatistikler, $t$-testi, Kruskal Wallis $H$ testi ve Pearson korelasyon katsayısı kullanılmıştır. Hata payı 0.05 olarak alınmıştır. Analiz sonuçlarına göre; beden eğitimi öğretmenlerinin yarı demokratik liderlik stili sergiledikleri sonucuna ulaşılmıştır. Öğretmenlerin öğrenen özerkliğini destekleme davranışlarını gerekli görme düzeyleri sergileme düzeylerinden daha düşüktür. Beden eğitimi öğretmenleri, özerklik desteği alt boyutları arasında en çok değerlendirme süreci desteğini gerekli buldukları ve sergiledikleri görüşündedir. Ayrıca öğretmenlerin cinsiyetlerine, okul düzeylerine ve sını mevcut gruplarına göre liderlik stilleri arasında anlamlı bir fark elde edilmemiş; cinsiyet, okul düzeyi ve sınıf mevcut gruplarına göre de öğrenen özerkliğini destekleme davranışları arasında anlamlı bir fark bulunmamıştır. Beden eğitimi öğretmenlerin öğretmen liderlik stilleri ve öğrenen özerkliğini destekleme davranışları arasında negatif yönlü, mesleki çalışma yılı ve öğrenen özerkliğini destekleme davranışları arasında da pozitif yönlü anlamlı bir ilişki vardır. Araştırma sonuçlarına göre, beden eğitimi öğretmenlerinin yarı demokratik liderlik stiline sahip oldukları ve öğrenen özerkliğini gerekli görme ile sergilemeleri arasında tutarlıık bulunmadığı belirlenmiştir.

Anahtar Kelimeler: Öğrenen özerkliği, liderlik stilleri, beden eğitimi öğretmeni

\section{Giriş}

Günümüz ihtiyaçları doğrultusunda nitelikli insan gücünün yetiştirilmesi için gerekli görülen eğitim ve öğretimdeki değişimler ve yenilikler geleneksel yöntemlerden öğrenen merkezli anlayışa doğru evrilmiştir. Problem çözebilen, karar verme becerileri gelişmiş, eleştirel ve inovatif düşünebilen bireyler yetiştirmeye duyulan intiyaç, eğitim programlarında çeşitli değişikler yapılma zorunluluğu doğurmuştur (MEB, 2017). Eğitim ve öğretim geleneksel anlayıştan uzaklaşarak yapılandırmacı yaklaşım çerçevesinde biçimlenmeye başlamıştır (Arslan, 2007). Eğitim sistemi kapsamında yer alan beden eğitimi ve spor dersi için de yapılandırmacı öğrenme anlayışına uyumlu öğretim programları hazırlanmış ve uygulanmaya başlanmıştır (MEB, 2006). Yapılandırmacılığın bir gereği olarak psikomotor öğrenmeler için yapılan öğretim planlamaları ile ilgili etkinliklerin öğrenci merkezli olmasının önem taşıdığı belirtilmektedir (Topkaya, 2007).

Yapılandırmacı yaklaşımda bilgi, öğrenci tarafından yapılanmakta ve öğrencilerin kendi öğrenmelerinden sorumlu oldukları belirtilmektedir (Brooks ve Brooks, 1993). Bu çerçevede öğretmenden beklenen roller ise bilgiyi yapılandırmaları için öğrencileri güdüleyen, onlara fırsatlar 
sunan, rehberlik eden ve anlamanın gerçekleştirilmesi için önemli rol oynayan kişiler olduğu ifade edilmektedir (Driver, Aasoko, Leach, Mortimer ve Scott, 1994). Bu bilgilerden hareketle, yapılandırmacı yaklaşımda öğrencinin; çevresini ve deneyimlerini bağımsız, 'özerk' bir biçimde algılama kapasitesini geliştirmesi ve kendi perspektifinden bilişsel yapılarını inşa etmesi gerekliliği (Aydın, 2006) öğretmenin öğrenene sağlayacağı özerklik kavramını önemli kılmıştır.

Özerklik, öğrenenin öğrenme sürecinde gereken sorumluluğu üstlenmesi (Holec, 1991), öğrenmeyle ilgili kararları kendisinin alabilmesi (Wang, 2011) olarak tanımlanmaktadır. Bireye öğrenme sürecinde sağlanan özerklik, arttıılan ilgi, daha üst düzeyde performans ortaya koymasını sağladığından (Ryan ve Deci, 2000) ve içsel motivasyonu arttırdığından dolayı (Scharle ve Szabo, 2000) öğretmenler tarafından öğrenen özerkliğinin desteklenmesi gerektiği belirtilmektedir (Oğuz, Altınkurt, Yılmaz ve Hatipoğlu, 2014). Bu bilgiler ışığında öğretmenlerin, öğrencilerin ilgi, istek, duygu ve düşüncelerini rahatça dile getirebildikleri, karar verebildikleri, kendi öğrenme yöntemlerini belirlemelerine olanak vererek öğrenme sürecinde özerklik desteği sağlayabilecekleri ifade edilmektedir (Oğuz, 2013b). Alanyazındaki çalışmalar (Brooks ve Brooks, 1993; Wang, 2011) yapılandırmacı öğrenme ortamlarında öğretmenlerin, öğrenen özerkliğini destekleme sorumlulukları olduğuna işaret etmektedir. Beden eğitiminin fiziksel aktiviteye yaşam boyu katıımını teşvik etme konusundaki geniş kapsamlı hedefi göz önüne alındığında da, öğretmenlerin özerk öğrenmeyi geliştirmek için pedagojik stratejileri keşfetmelerinin şart olduğu ifade edilmektedir (Perlman ve Webster, 2013). Günümüzde hala öğrencilerin büyük bir bölümünün bağımlı öğrenmenin desteklendiği ortamlarda öğrenim görüyor olmaları öğrenme ortamlarında öğretmenler tarafından özerklik desteğinin sağlamasını da önemli kılmaktadır (McGarry, 1995).

Yapılandırmacı öğrenme ilkelerini uygulayan bir öğretmenin, öğrenciye etkin ve demokratik bir öğrenme ortamı sağlaması, özerkliğine önem vermesi ve destek olması gerektiği ifade edilmektedir (Yager, 1991; Brooks ve Brooks, 1993; Olsen, 1999). Bu nedenle de öğretmenlerin sahip olmuş oldukları liderlik stillerinin önemsenmesi gereken bir kavram olduğu düşünülmektedir. Çünkü öğrenmeyi merkeze alma, öğrenciler için birer model olma, eğitim ve okul ile ilgili gelişimleri uygulama, yeni yaklaşımları cesaretle uygulama gibi özellikler lider öğretmenin nitelikleri arasında sayılmaktadır (Maxwell, 2003; Can ve vd., 2011).

Liderlik, görüşleri, eylemleri etkileme ve yönlendirme; belli bir grubu hedeflere ulaştırmada etkileme; insan ilişkileri sürecinde başkalarının davranışlarını etkileme ve yönlendirme olarak tanımlanmaktadır (Ensari, 1993). Liderlik kavramı çeşitli kuramlara dayanmakta ve bu kuramlar Özellik Kuramı, Davranışçılık Kuramı ve Durumsalık Kuramı olarak literatürde yer almaktadır (Deniz ve Hasançebioğlu, 2003). Özellik kuramı, lider konumunda olan insanların ortak özelliklerini belirlemeyi amaçlayan bir kuram iken durumsal kuram ise liderliği değişmez davranışlar dizisi olarak ele almak yerine, çeşitli durumlarda farklılaşan davranışlar olarak değerlendirmişlerdir (Tevruz, Artan ve Barut, 1999, s. 199). Davranışçı kuram ise liderliğe konu olan grupların yapısına ve işleyişine odaklanmış, liderlerin grup içinde nasıl davrandığını değerlendirmeye çalışmışlardır (Koçel, 1989, s. 263).

Davranışsal liderlik yaklaşımı temsilcileri arasında McGregor'un yaklaşımı " $X$ " ve " $Y$ " kuramına dayanmaktadır. Klasik yönetim anlayışına dayanan davranışları $X$ kuramı adı altında, ilişkilere önem veren yaklaşıma dayanan davranışların ise $Y$ kuramı adı altında toplandığı belirtilmiştir (Küçüközkan, 2015). Bu kuram çerçevesinde insanların edilgen yani pasif oldukları varsayımına dayanan $X$ ve insanların motive olmaya, sorumluluk almaya açık olduklarını savunan $Y$ kuramı biçiminde iki tür liderlik öngörülmüştür (McGregor, 1970). Liderlerin insan davranışları hakkındaki inançlarının onlara göstereceği davranışı etkileyeceği temeline dayanan kuramdan hareketle, $X$ kuramını benimseyen öğretmenlerin baskıcı (otokratik) ve yönlendirici, $Y$ kuramını benimseyen öğretmenlerin ise demokratik ve katıımcı liderler oldukları ifade edilmektedir (Deniz ve Hasançebioğlu, 2003). 
Otokratik liderlik stiline sahip öğretmenin, güç, üstünlük ve baskı ile uyumu başarmayı amaçladığı (Moore, 2001), karar verici, itaat bekleyen ve faaliyetlerin belirleyicisi bir role sahip olduğu ifade edilmektedir. Bu tür liderlik stilinde öğrencilerin özdenetim kazanmalarının oldukça zor olduğu ifade edilmektedir (Güllü ve Arslan, 2009). Demokratik/katılımcı liderlik stiline sahip öğretmenlerin ise öğrenci-öğretmen işbirliğini merkeze alarak öğrenme durumlarında öğrencilerin karar verici rolde olmalarını sağlayan, yol gösterici ve ders aktivitelerinde çeşitlilik sağlayan bir davranışa sahip oldukları ifade edilmektedir (ilgar, 2000). Bu bilgiler ışığında etkili lider; öğretmen çatışma yönetimi becerisine sahip, öğrenmek isteyenlere bilgi kaynaklarının ve bilgilerin yöntemlerini ve tekniklerini gösteren eğitim çalışanı olarak tanımlanmakta (Can ve ark., 2011) ve öğretmenlerin bir lider olarak, formal öğretimsel ilişkileri informal ilişkilerle destekleyerek, öğrencilere güvenerek ve güven vererek, sınıfta bir rehber, koordinatör ve danışman rollerini oynayabilmesi gerektiği ifade edilmektedir (Arat, 2001).

Alanyazın incelendiğinde öğretmenlerin öğrenen özerkliğini destekleme davranışlarına (Black ve Deci, 2000; Chiu, 2012; Gömleksiz ve Bozpolat, 2012; Güvenç ve Güvenç, 2014; Kozak, 2017; Oğuz, 2013a, 2013b; Oğuz ve ark., 2014; Özkal ve Demirkol, 2014; Öztürk, 2012; Perlman ve Webster, 2011; Reeve, Bolt ve Cai, 1999; Scharle ve Szabo, 2000; Sierens ve diğerleri, 2009; Üstünoğlu, 2009; Wulf, Chiviacowsky ve Drews, 2015) ve liderlik stillerine ilişkin araştırmalar (Altınkurt ve Yılmaz, 2012; Angelle ve DeHart, 2011; Angelle, Nixon, Norton ve Niles, 2011; Can, 2009; Çelik ve Tamer, 2014; Greenlee, 2007; Güllü ve Arslan, 2009; Kıranlı, 2013; Lieberman ve Friedrich, 2007; Yiğit, Doğan ve Uğurlu, 2013) literatürde yer almaktadır. Ancak beden eğitimi öğretmenlerinin özerklik destekleyici davranışlarının ve liderlik stillerinin belirlenmesine yönelik araştırmaların az olduğu belirlenirken; aynı zamanda öğretmen liderliği ile öğrenen özerkliğini destekleme davranışı arasındaki ilişkiyi araştıran alana özgü bir araştırmaya da rastlanılmamıştır. Beden eğitimi ders ortamlarında özerkliği destekleyici uygulama koşullarının sağlanmasının motor beceri öğrenimini olumlu etkilediği, motivasyonu ve performansı arttırdığı (Reeve ve Tseng, 2011; Sanli Patterson, Bray ve Lee, 2013; Wulf, Chiviacowsky ve Cardozo, 2014: Wulf, Freitas ve Tandy, 2014), sağlanan özerkliğin, öğrencilerin yeteneklerine güven duymalarına olanak verdiği ve olumsuz duygusal tepkilerin kontrolüne olan ihtiyacı azalttı (Hooyman, Wulf ve Lewthwaite, 2014) ifade edilirken; aynı zamanda okullarda yapılandırmacı öğrenme ortamlarının etkili bir biçimde gerçekleştirilebilmesi için öğretmenlerin özerklik destekleyici davranışlar sergilemeleri ve liderlik rollerini yerine getirmeleri gerektiği de belirtilmektedir (Yılmaz, Oğuz ve Altınkurt, 2017). Beden eğitimi öğretmeninin özel alan yeterlilikleri arasında da yer alan 'liderlik yapabilme' yeterliliğine sahip beden eğitimi öğretmeni olma (MEB, 2006) bilgisinden hareketle de beden eğitimi öğretmenlerinin öğrenme ve öğretme sürecinde öğrenen özerkliğini destekleme davranışlarına ilişkin görüşlerinin ve yüksek düzeyde hangi liderlik stilini sergilediklerini belirlemenin önemli olduğu düşünülmektedir.

Bu bilgiler doğrultusunda araştırmanın genel amacı, ortaokul ve lise beden eğitimi öğretmenlerinin, öğrenen özerkliğini destekleme davranışları ile liderlik stillerini cinsiyet, okul türü ve sınıf mevcut grupları değişkenlerine göre incelemektir. Ayrıca öğretmenlerin öğrenen özerkliğini destekleme davranışları, liderlik stilleri ve mesleki çalışma yılları arasındaki ilişkinin incelenmesi de bu çalışmanın amaçları arasındadır. Bu genel amaca ulaşmak için aşağıdaki sorulara yanıt aranmıştır:

1. Beden Eğitimi Öğretmenlerinin öğrenen özerkliğini destekleme davranışlarının gerekliliği ve sergilenmesine ilişkin görüşleri nedir?

2. Beden Eğitimi Öğretmenlerinin öğretmen liderlik stilleri nedir?

3. Beden Eğitimi Öğretmenlerinin öğrenen özerkliğini destekleme davranışlarının gerekliliği ve sergilenmesine ilişkin görüşleri ve öğretmen liderlik stilleri cinsiyet, okul türü ve sınıf mevcut grupları değişkenlerine göre farklılık göstermekte midir? 
4. Beden Eğitimi Öğretmenlerin öğrenen özerkliğini destekleme davranışlarının gerekliliğine ve sergilenmesine ilişkin görüşleri ile öğretmen liderlik stilleri ve mesleki çalışma yılları arasında anlamlı bir ilişki var mıdır?

\section{Yöntem}

\section{Araştırma Modeli}

Araştırma çerçevesinde belirlenen hipotezlerin test edilmesinde betimsel tarama modeli kullanımıştır. Tarama modeli, geçmişte var olmuş ya da halen var olan durumu olduğu şekliyle betimlemeyi amaçlayan araştırma modelidir (Karasar, 2008, s.77). Bu model ile araştırma problemlerine, belirli bir zaman diliminde çok sayıda denekten elde edilen verilerin analizi ile cevap aranır (Arseven, 2001).

\section{Evren ve Örneklem}

Araştırmanın evrenini 2018-2019 eğitim öğretim yılında, Mersin ilinde görev yapan ortaokul ve lise beden eğitimi öğretmeni oluşturmaktadır. Araşstırmanın örneklemini ise kolay ulaşılabilir örnekleme yöntemi ile Mersin ilinde ortaokul ve lisede görev yapan 132 beden eğitimi öğretmeni oluşturmaktadır. Araştırmaya katılan öğretmenlerin \%41.7'si kadın ( $n=55)$, \%58.3'ü erkektir ( $n=77$ ). Katılımcıların \%70.5'i ortaokul ( $n=93$ ) ve \% 29.5'i liselerde $(n=39)$ görev yapmaktadır. Araştırmaya katılan beden eğitimi öğretmenlerin mesleki çalışma süreleri 1-34 yıl arasında değişmektedir. Öğretmenlerin derslerine girdikleri sınıf mevcutları ise üç grup halinde sınıflandırılmış, 20-25 arası sınıf mevcuduna sahip \%15.2 ( $n=20), 26-35$ arası \%54.5 ( $n=72)$ ve 36 ve üstü sınıf mevcuduna sahip \%30.3 ( $n=40)$ olarak belirtilmişstir.

\section{Veri Toplama Araçları}

Araştırmada veri toplama aracı olarak Öğrenen Özerkliğini Destekleme Ölçeği ve Öğretmen Liderlik Stilleri Ölçeği kullanılmıştır. Öğrenen Özerkliğini Destekleme Ölçeği, Oğuz (2013a) tarafından öğretmenlerin öğrenen özerkliğini destekleme davranışlarının gerekliliği ve sergilenmesine ilişkin görüşlerini ortaya koymak amacıyla geliştirilmiştir. Ölçekte, Likert tipi 16 madde bulunmaktadır ve (1) Hiçbir zaman ile (5)-Her zaman aralığında yanıtlanır. Ölçek, "duygu ve düşünce desteği", "öğrenme süreci desteği", "değerlendirme desteği" olmak üzere üç alt boyuttan oluşmaktadır. Ölçekte ters puanlanan madde bulunmamaktadır. Ölçeğin tamamından hem gereklilik hem de sergileme derecesi için toplam puan alınabilmektedir. Ölçeğin Açımlayıcı Faktör Analizine (AFA) ilişkin faktör yük değerleri; gereklilik için 0.49-0.73; sergilenme için, 0.60-0.75 arasında değişmektedir. Üç faktörün açıkladığı toplam varyans gereklilik için \%56.25; sergilenme için \%62.06'dır. Ölçeğin Doğrulayıcı Faktör Analizi (AFA) sonucunda oluşturulan modele uygun ki-kare $\left(X_{2}\right)$ değeri istatistiki anlamlılı düzeyleri gereklilik ( $\left.X_{2} / \mathrm{sd}=2.33\right)$ ve sergileme (X2/sd= 2.93) için hesaplanmış, uyum indeksleri de hem gereklilik $(\mathrm{GFI}=0.92, \mathrm{AGFI}=0.89, \mathrm{RMSEA}=0.064, \mathrm{CFI}=0.97)$ hem de sergileme için $(\mathrm{GFI}=0.90, \mathrm{AGFI}=0.86$, $\mathrm{RMSEA}=0.077, \mathrm{SRMR}=0.052, \mathrm{CFI}=0.97$ ) önerilen modelin uygun olduğunu göstermiştir. Ölçeğin iç tutarlıı̆ına ilişkin Cronbach Alpha değerleri ise, gereklilik için 0.89; sergilenme için de 0.92'dir. Bu araştırmada ölçeğin Cronbach Alpha katsayıları hesaplanarak yeniden test edilmiştir. Cronbach Alpha katsayıları gereklilik için 0.85 , sergilenme için 0.90 olarak hesaplanmıştır.

Liderlik Stilleri Ölçeği. Deniz ve Hasançebioğlu (2003) tarafından geliştirilmiş ve McGregor'un X ve Y kuramına göre hazırlanmış 17 maddeden oluşmuştur. Ölçek tek boyuttan meydana gelmektedir. 5'li Likert türünde ve dereceleme maddeleri "(1) Hiç Katılmıyorum, (2) Katılıyorum, (3) Orta derece katılıyorum, (4) Katılıyorum, (5) Tamamen Katılıyorum" seçeneklerinden oluşmaktadır. Ölçekte 5, 6, 12, 13, 14, 16 ve 17. maddeler ters puanlanır. Ölçekten en fazla 85 en az ise 17 puan alınabilmektedir. Yüksek puan "Y" teorisine uygun olarak demokratik/katılımcı liderlik stiline, düşük puan ise " $X$ " teorisine uygun olarak otokratik/baskıcı liderlik stiline sahip olduğunu göstermektedir. Ölçeğin iç 
güvenirlik katsayısı (Cronbach Alpha) 0,88 olarak bulunmuştur. Bu çalışmada da anketin iç güvenirlik katsayısı 0,73 olarak hesaplanmıştır. Öğretmen Liderlik Stilleri Ölçeği ile yapılacak araştırmaların analizlerinde, ölçekten elde edilen toplam puan sürekli bir değişken olarak kullanılabileceği gibi, yapılan çeyrek değer hesaplamalarından da hareketle, elde edilen puanlar sınıflamalı bir ölçek mantığıyla (a) Demokratik/Katıımcı, (b) Yarı demokratik ve (c) Otokratik/Baskıcı liderlik stilleri olarak sınıflandırılarak da kullanılabilmektedir.

Tablo 1. Liderlik Stilleri Ölçeğinden Alınacak Puanların Değerlendirme Ölçütleri

\begin{tabular}{cc}
\hline Puan aralığı & Liderlik Stili \\
\hline $17-64$ & Otokratik/Baskıcı \\
$65-76$ & Yarı Demokratik \\
$77-85$ & Demokratik/Katılımcı \\
\hline
\end{tabular}

Kişisel bilgi formu. Araştırmaya katılan tüm öğretmenlerin doldurması için araştırmacılar tarafından oluşturulmuştur. Bilgi formunda araştırmaya katılan öğretmenlerin cinsiyetleri, okul türleri, mesleki çalışma yılı ve derslerine girmiş oldukları sınıf mevcutları ile ilgili bilgiler yer almaktadır.

\section{Verilerin Analizi}

Araştırmada öğretmenlerin, öğrenen özerkliğini destekleme davranışlarının gerekliliğine ve sergilenmesine ilişkin görüşleri ile liderlik stillerini belirlemek amacıyla betimsel istatistikler, ikili karşılaştırmalarda t-testi, üç ve daha fazla boyutu olan karşılaştırmalarda grup sayıları 30'dan az olduğu için Kruskal Wallis H testi analizi kullanıımıştır. Araştırmada öğrenen özerkliğini destekleme davranışlarının gerekliliğine ve sergilenmesine ilişkin görüşleri ile öğretmen liderlik stilleri ve mesleki çalışma yılı arasındaki ilişkinin belirlenmesi için ise Pearson korelasyon katsayısı kullanılmışıı. Verilerin normal dağılıma sahip olup olmadığını belirlemek için ise Skewness (Yayılma) ve Kurtosis (Çarpıklık) değerlerine bakılmıştır. Hata payı 0.05 olarak alınmıştır. Verilerin normal dağıımına ait Skewness ve Kurtosis değerleri Tablo z'de belirtilmiştir.

Tablo 2. Katılanların Skewness (Yayılma) ve Kurtosis (Çarpıklık) değerleri

\begin{tabular}{lllcc}
\hline Ölçekler & Alt Boyutlar & $N$ & Skewness & Kurtosis \\
\hline Öğrenen Özerkliğini & Duygu ve düşünce desteği & 132 &, 544 &,- 525 \\
Destekleme & Öğrenme süreci desteği & 132 &, 746 &, 062 \\
(Gereklilik) & Değerlendirme desteği & 132 &, 502 &,- 430 \\
& Genel Gereklilik & 132 &, 474 &,- 417 \\
Öğrenen Özerkliğini & Duygu ve düşünce desteği & 132 &, 329 &,- 633 \\
Destekleme & Öğrenme süreci desteği & 132 &, 746 &, 062 \\
(Sergileme) & Değerlendirme desteği & 132 &, 140 &,- 110 \\
& Genel Sergileme & 132 &, 334 &,- 083 \\
Liderlik Stili & & 132 &, 100 &,- 659 \\
\hline
\end{tabular}

Skewness ve Kurtosis değerlerine bakıldığında, değerlerin kabul edilebilirlik sınırları içerisinde olduğu görülmektedir. Skewness için +1 ile -1 arasında ve Kurtosis için ise +2 ile -1 arasında olması gerektiği belirtilen (Huck, 2008) değerler araştırmada kullanılan tüm ölçekler ve alt boyutları için istenilen aralıktadır. Elde edilen bulgulara göre de veriler normal dağııma sahiptir yorumu yapılabilir.

\section{Bulgular}

Bu bölümde araştırmanın amaçları doğrultusunda önce öğretmenlerin, öğrenen özerkliğini destekleme davranışlarına ilişkin görüşlerine ve liderlik stillerine; daha sonra bu görüşlerin cinsiyet, 
okul türü ve sınıf mevcudu değişkenlerine göre karşılaştırılmasına ilişkin bulgulara yer verilmiştir. Son olarak da öğretmenlerin öğrenen özerkliğini destekleme davranışlarının gerekliliğine ve sergilenmesine ilişkin görüşleri ile öğretmen liderlik stilleri ve mesleki çalışma yılları arasındaki ilişkiye ilişkin bulgulara yer verilmiştir. Tablo 3'de beden eğitimi öğretmenlerin, öğretmen liderliği ve öğrenen özerkliğini destekleme davranışlarına ilişkin görüşleri yer almaktadır.

Tablo 3. Öğretmenlerin, Öğrenen Özerkliğini Destekleme Davranışlarının Gerekliliği ve Sergilenmesine ve Öğretmen Liderlik Stillerine Ilişkin Görüşleri

\begin{tabular}{llccc}
\hline Ölçekler & Alt Boyutlar & N & X & SS \\
\hline Öğrenen Özerkliğini Destekleme & Duygu ve düşünce desteği & 132 & 1,65 &, 53 \\
(Gereklilik) & Öğrenme süreci desteği & 132 & 1,88 &, 70 \\
& Değerlendirme desteği & 132 & 1,94 &, 72 \\
& Genel Gereklilik & 132 & 1,79 &, 55 \\
Öğrenen Özerkliğini Destekleme & Duygu ve düşünce desteği & 132 & 2,02 &, 58 \\
(Sergileme) & Öğrenme süreci desteği & 132 & 1,88 &, 70 \\
& Değerlendirme desteği & 132 & 2,34 &, 73 \\
& Genel Sergileme & 132 & 2,20 &, 55 \\
Liderlik Stili & Otokratik/Despot & 55 & 57,62 & 4,23 \\
& Yarı demokratik & 57 & 69,79 & 3,32 \\
& Demokratik/Katılımcı & 20 & 80,60 & 3,03 \\
& Genel toplam & 132 & 66,36 & 9,03 \\
\hline
\end{tabular}

Tablo 3'e göre beden eğitimi öğretmenlerin öğrenen özerkliğini destekleme davranışlarını gerekli görme düzeyleri (=1.79, Ss=0.55) sergileme düzeylerinden (=2.20, Ss=0.55) daha düşüktür. Beden eğitimi öğretmenleri, özerklik desteği alt boyutları arasında ise en çok değerlendirme süreci desteğini gerekli buldukları (=1.94, Ss=0.72) ve sergiledikleri (=2.34, Ss=0.73) görüşündedir. Ayrıca beden eğitimi öğretmenlerin 55'i (\%41,7) Otokratik/Baskıcl; 57'si (\%43,2) Yarı Demokratik ve 20'si de $(\% 15,2)$ Demokratik Katılımcı olarak gözlemlenmiştir. Analiz sonuçlarına göre; beden eğitimi öğretmenlerinin "Yarı Demokratik Liderlik" stili sergiledikleri (=69.79, SS=3.32) sonucuna ulaşılmıştır. Tablo 4'de beden eğitimi öğretmenlerinin ölçeklerden aldıkları puanların cinsiyete göre farkıı̆ı̆ını test etmek amacıyla yapılan bağımsız gruplar t testi analiz sonuçları yer almaktadır.

Yapılan t-testi analiz sonucuna göre (Tablo 4). Öğrenen Özerkliğini Destekleme Ölçeği'nin gereklilik ve sergilenmesine ilişkin tüm alt boyutlarında ve toplam puanda cinsiyete göre anlamlı bir fark elde edilmemiştir $\mathrm{t}_{\text {Gereklilik }}(132)=-0.99, \mathrm{p}>.05 ; \mathrm{t}_{\text {Sergileme }}(132)=-1.55, \mathrm{p}>$.05]. Ayrıca beden eğitimi öğretmenlerin cinsiyetlerine göre liderlik stilleri arasında da anlamlı bir fark elde edilmemiştir [t(132)=0.61; $p>$.05].

Beden eğitimi öğretmenlerinin okul düzeyine göre öğrenen özerkliğinin destekleme davranışları ve liderlik stilleri ölçeklerinden aldıkları puan ortalamalarının bağımsız gruplar t testi sonuçları Tablo 5'de yer almaktadır. Analiz sonuçlarına göre beden eğitimi öğretmenlerinin okul düzeylerine göre Öğrenen Özerkliğini Destekleme Ölçeği'nin gereklilik ve sergilenmesine ilişkin tüm alt boyutlarında ve toplam puanda anlamlı bir fark elde edilmemiştir $\left[t_{\text {Gerekliik }}(132)=-0.22, p>05 ; t_{\text {Sergileme }}(132)=-1.37, p>.05\right]$. Aynı zamanda beden eğitimi öğretmenlerinin liderlik stilleri de okul düzeyine göre farklılaşmamaktadır [t(132) $=0.41 ; p>05]$. 
Tablo 4. Öğretmenlerin Ölçeklerden Aldıkları Puanların Cinsiyete Göre t-testi Sonuçları

\begin{tabular}{|c|c|c|c|c|c|c|c|c|}
\hline & & Cinsiyet & $\mathbf{N}$ & & SS & $\mathrm{t}$ & sd & $p$ \\
\hline \multirow{8}{*}{$\begin{array}{l}\text { Öğrenen } \\
\text { Özerkliği } \\
\text { Destekleme } \\
\text { Davranışı } \\
\text { (Gereklilik) }\end{array}$} & \multirow{2}{*}{$\begin{array}{l}\text { Duygu ve Düşünce } \\
\text { Desteği }\end{array}$} & Kadın & 55 & 1,59 & .49 & \multirow[t]{2}{*}{1,02} & \multirow[t]{2}{*}{13} & \multirow[t]{2}{*}{.30} \\
\hline & & Erkek & 77 & 1,69 & .55 & & & \\
\hline & \multirow{2}{*}{$\begin{array}{l}\text { Öğrenme Süreci } \\
\text { Desteği }\end{array}$} & Kadın & 55 & 1,79 & .60 & \multirow[t]{2}{*}{1,20} & \multirow[t]{2}{*}{13} & \multirow[t]{2}{*}{23} \\
\hline & & Erkek & 77 & 1,94 & .76 & & & \\
\hline & \multirow{2}{*}{$\begin{array}{l}\text { Değerlendirme } \\
\text { Desteği }\end{array}$} & Kadın & 55 & 1,92 & .66 & \multirow[t]{2}{*}{,- 27} & \multirow[t]{2}{*}{13} & \multirow[t]{2}{*}{.78} \\
\hline & & Erkek & 77 & 1,96 &, 76 & & & \\
\hline & \multirow[t]{2}{*}{ Genel Gereklilik } & Kadın & 55 & 1,74 & .51 & \multirow[t]{2}{*}{,- 99} & \multirow[t]{2}{*}{13} & \multirow[t]{2}{*}{.32} \\
\hline & & Erkek & 77 & 1,83 & .58 & & & \\
\hline \multirow{10}{*}{$\begin{array}{l}\text { Öğrenen } \\
\text { Özerkliği } \\
\text { Destekleme } \\
\text { Davranışı } \\
\text { (Sergileme) }\end{array}$} & \multirow{2}{*}{$\begin{array}{l}\text { Duygu ve Düşünce } \\
\text { Desteği }\end{array}$} & Kadın & 55 & 1,94 & .57 & \multirow[t]{2}{*}{1,45} & \multirow[t]{2}{*}{13} & \multirow[t]{2}{*}{14} \\
\hline & & Erkek & 77 & 2,09 & .58 & & & \\
\hline & \multirow{2}{*}{$\begin{array}{l}\text { Öğrenme Süreci } \\
\text { Desteği }\end{array}$} & Kadın & 55 & 1,79 & 60 & \multirow[t]{2}{*}{1,20} & \multirow[t]{2}{*}{13} & \multirow[t]{2}{*}{, 23} \\
\hline & & Erkek & 77 & 1,94 & .76 & & & \\
\hline & \multirow{2}{*}{$\begin{array}{l}\text { Değerlendirme } \\
\text { Desteği }\end{array}$} & Kadın & 55 & 2,31 &, 78 & \multirow[t]{2}{*}{,- 45} & \multirow[t]{2}{*}{13} & \multirow[t]{2}{*}{, 65} \\
\hline & & Erkek & 77 & 2,37 & ,69 & & & \\
\hline & \multirow[t]{2}{*}{ Genel Sergileme } & Kadın & 55 & 2,12 & .55 & \multirow[t]{2}{*}{1,55} & \multirow[t]{2}{*}{13} & \multirow[t]{2}{*}{12} \\
\hline & & Erkek & 77 & 2,27 & .54 & & & \\
\hline & \multirow[t]{2}{*}{ Liderlik Stili } & Kadın & 55 & 66,93 & 9,71 &, 61 & 13 & .54 \\
\hline & & Erkek & 77 & 65,95 & 8,56 & & & \\
\hline
\end{tabular}

Tablo 5. Öğretmenlerin Ölçeklerden Aldıkları Puanların Okul Düzeyine Göre t-testi Sonuçları

\begin{tabular}{|c|c|c|c|c|c|c|c|c|}
\hline & & Okul Düzeyi & $\mathbf{N}$ & $\mathrm{X}$ & SS & $\mathbf{t}$ & df & $p$ \\
\hline \multirow{8}{*}{$\begin{array}{l}\text { Öğrenen } \\
\text { Özerkliği } \\
\text { Destekleme } \\
\text { Davranışı } \\
\text { (Gereklilik) }\end{array}$} & \multirow[t]{2}{*}{ Duygu ve Düşünce Desteği } & Ortaokul & 93 & 1,66 & .53 & \multirow[t]{2}{*}{18} & \multirow[t]{2}{*}{130} & \multirow[t]{2}{*}{,85 } \\
\hline & & Lise & 39 & 1,64 & .54 & & & \\
\hline & \multirow[t]{2}{*}{ Öğrenme Süreci Desteği } & Ortaokul & 93 & 1,89 & .72 & \multirow[t]{2}{*}{.42} & \multirow[t]{2}{*}{130} & \multirow[t]{2}{*}{67} \\
\hline & & Lise & 39 & 1,84 & 68 & & & \\
\hline & \multirow[t]{2}{*}{ Değerlendirme Desteği } & Ortaokul & 93 & 1,88 &, 71 & \multirow[t]{2}{*}{$-1,46$} & \multirow[t]{2}{*}{130} & \multirow[t]{2}{*}{14} \\
\hline & & Lise & 39 & 2,08 & .72 & & & \\
\hline & \multirow[t]{2}{*}{ Genel Gereklilik } & Ortaokul & 93 & 1,79 & .55 & \multirow[t]{2}{*}{,- 22} & \multirow[t]{2}{*}{130} & \multirow[t]{2}{*}{82} \\
\hline & & Lise & 39 & 1,81 & .56 & & & \\
\hline \multirow{10}{*}{$\begin{array}{l}\text { Öğrenen } \\
\text { Özerkliği } \\
\text { Destekleme } \\
\text { Davranışı } \\
\text { (Sergileme) }\end{array}$} & \multirow[t]{2}{*}{ Duygu ve Düşünce Desteği } & Ortaokul & 93 & 2,00 & .58 & \multirow[t]{2}{*}{,- 86} & \multirow[t]{2}{*}{130} & \multirow[t]{2}{*}{.38} \\
\hline & & Lise & 39 & 2,09 & .57 & & & \\
\hline & \multirow[t]{2}{*}{ Öğrenme Süreci Desteği } & Ortaokul & 93 & 1,89 &, 72 & \multirow[t]{2}{*}{.42} & \multirow[t]{2}{*}{130} & \multirow[t]{2}{*}{67} \\
\hline & & Lise & 39 & 1,84 & 68 & & & \\
\hline & \multirow[t]{2}{*}{ Değerlendirme Desteği } & Ortaokul & 93 & 2,27 & .70 & \multirow[t]{2}{*}{$-1,75$} & \multirow[t]{2}{*}{130} & \multirow[t]{2}{*}{, 08} \\
\hline & & Lise & 39 & 2,51 & .78 & & & \\
\hline & \multirow[t]{2}{*}{ Genel Sergileme } & Ortaokul & 93 & 2,17 & .55 & \multirow[t]{2}{*}{$-1,37$} & \multirow[t]{2}{*}{130} & \multirow[t]{2}{*}{17} \\
\hline & & Lise & 39 & 2,31 & .54 & & & \\
\hline & \multirow[t]{2}{*}{ Liderlik Stili } & Ortaokul & 93 & 66,57 & 9,85 &, 41 & 130 & 67 \\
\hline & & Lise & 39 & 65,85 & 6,77 & & & \\
\hline
\end{tabular}

Tablo 6'da beden eğitimi öğretmenlerinin sınıf mevcut grupları değişkenine göre öğrenen özerkliğini destekleme davranışları ve liderlik stilleri ölçek puanları arasındaki farkların anlamlıı̆̆ına yönelik olarak yapılan Kruskal Wallis $\mathrm{H}$ testi sonuçları yer almaktadır. 
Tablo 6. Öğretmenlerin Sınıf Mevcut Grupları Değişkenine Göre Ölçek Puanları Arasındaki Farkın Anlamlıı̆ına Yönelik Kruskal Wallis H-testi Sonuçları

\begin{tabular}{|c|c|c|c|c|c|c|c|}
\hline & & Öğrenci Sayısı & $\mathbf{N}$ & $x$ & $X^{2}$ & sd & $p$ \\
\hline \multirow{12}{*}{$\begin{array}{l}\text { Öğrenen } \\
\text { Özerkliği } \\
\text { Destekleme } \\
\text { Davranışı } \\
\text { (Gereklilik) }\end{array}$} & $\begin{array}{l}\text { Duygu ve Düşünce } \\
\text { Desteği }\end{array}$ & $20-25$ & 20 & 76,35 & 2,97 & 2 &, 22 \\
\hline & & $26-35$ & 72 & 67,90 & & & \\
\hline & & 36 ve üstü & 40 & 59,06 & & & \\
\hline & Öğrenme Süreci & $20-25$ & 20 & 77,30 & 2,58 & 2 &, 27 \\
\hline & & $26-35$ & 72 & 66,77 & & & \\
\hline & & 36 ve üstü & 40 & 60,61 & & & \\
\hline & Değerlendirme & $20-25$ & 20 & 80,50 & 5,23 & 2 & .07 \\
\hline & & $26-35$ & 72 & 67,81 & & & \\
\hline & & 36 ve üstü & 40 & 57,15 & & & \\
\hline & Genel Gereklilik & $20-25$ & 20 & 79,43 & 4,01 & 2 &, 13 \\
\hline & & $26-35$ & 72 & 67,28 & & & \\
\hline & & 36 ve üstü & 40 & 58,63 & & & \\
\hline \multirow{16}{*}{$\begin{array}{l}\text { Öğrenen } \\
\text { Özerkliği } \\
\text { Destekleme } \\
\text { Davranışı } \\
\text { (Sergileme) }\end{array}$} & Duygu ve Düşünce & $20-25$ & 20 & 73,78 & 2,39 & 2 & 30 \\
\hline & Desteği & & & & & & \\
\hline & & $26-35$ & 72 & 68,53 & & & \\
\hline & & 36 ve üstü & 40 & 59,21 & & & \\
\hline & Öğrenme Süreci & $20-25$ & 20 & 77,30 & 2,58 & 2 & 27 \\
\hline & & $26-35$ & 72 & 66,77 & & & \\
\hline & & 36 ve üstü & 40 & 60,61 & & & \\
\hline & Değerlendirme & $20-25$ & 20 & 69,30 & 2,70 & 2 &, 25 \\
\hline & & $26-35$ & 72 & 70,29 & & & \\
\hline & & 36 ve üstü & 40 & 58,28 & & & \\
\hline & Genel Sergileme & $20-25$ & 20 & 73,05 & 2,98 & 2 &, 22 \\
\hline & & $26-35$ & 72 & 69,40 & & & \\
\hline & & 36 ve üstü & 40 & 58,00 & & & \\
\hline & Liderlik Stili & $20-25$ & 20 & 65,20 & 1,16 & 2 & .56 \\
\hline & & $26-35$ & 72 & 63,87 & & & \\
\hline & & 36 ve üstü & 40 & 71,89 & & & \\
\hline
\end{tabular}

Analiz sonucunda sınıf mevcut gruplarına göre beden eğitimi öğretmenlerinin Öğrenen Özerkliğini Destekleme Ölçeği'nin gereklilik ve sergilenmesine ilişkin tüm alt boyutlarında ve toplam puanda anlamlı bir fark elde edilmemiştir $\left(x_{(2) \text { Gereklik }=4.01, p>.05 ;} x^{2}{ }_{(2) \text { Sergileme }}=2.98, p>.05\right)$. Aynı zamanda 
öğretmenlerin liderlik stilleri de sınıf mevcut gruplarına göre farklılaşmamaktadır $\left(x_{(2)}^{2}=1.16, p>.05\right)$. Beden eğitimi öğretmenlerin, öğretmen liderlik stilleri ile öğrenen özerkliğini destekleme davranışlarının gerekliliğine ve sergilenmesine ilişkin görüşleri ve mesleki çalışma yılları arasında anlamlı bir ilişki olup olmadığını belirlemek için yapılan korelasyon analizine ait bulgular Tablo 7'de yer almaktadır.

Tablo 7. Öğretmenlerin öğrenen özerkliğini destekleme davranışları, liderlik stilleri ve mesleki çalışma yılına ilişkin korelasyon tablosu ( $\mathrm{N}=132)$

\begin{tabular}{lccc}
\hline Değişkenler & Gereklilik & Sergileme & Liderlik Stili \\
\hline Çalışma yılı & $.32^{\prime \prime}$ & $.20^{\circ}$ & -.10 \\
Gereklilik & 1 & $.58^{\prime \prime}$ & $-.33^{\prime \prime}$ \\
Sergileme & $.58^{\prime \prime}$ & 1 & $-.25^{\prime \prime}$ \\
\hline
\end{tabular}

${ }^{*} \mathrm{p}<0,05 ;{ }^{* \star} \mathrm{p}<0,01$

Tablo 7'ye göre, beden eğitimi öğretmenlerin öğretmen liderlik stilleri ve öğrenen özerkliğini destekleme davranışları arasında negatif yönlü zayıf $\left(r_{\text {Gereklilik }}=-0.33, p<0,01, r_{\text {Sergileme }}=-0.25, p<0,01\right)$; mesleki çalışma yılı ve öğrenen özerkliğini destekleme davranışları arasında da pozitif yönlü ve zayıf anlamlı bir ilişki elde edilmiştir $\left(r_{\text {Gereklilik }}=0.32, p<0,01 ; r_{\text {Sergileme }}=0.20, p<0,05\right)$.

\section{Tartışma}

Bu araştırmada, ortaokul ve lise beden eğitimi öğretmenlerinin, öğrenen özerkliğini destekleme davranışları ile öğretmen liderlik stilleri cinsiyet, okul türü ve sınıf mevcut grupları değişkenlerine göre belirlenmeye çalışılmıştır. Ayrıca öğretmenlerin öğrenen özerkliğini destekleme davranışları, liderlik stilleri ve mesleki çalışma yılları arasındaki ilişki de incelenmiştir. Araştırmada ilk olarak beden eğitimi öğretmenlerin, öğrenen özerkliğini destekleme davranışları ve liderlik stillerine ilişkin görüşleri belirlenmiştir.

Araştırmada beden eğitimi öğretmenlerinin, öğrenen özerkliğini destekleme davranışlarını gerekli görme ve sergileme düzeylerinin düşük olduğu ve gerekli görme düzeylerinin sergileme düzeylerinden daha düşük olduğu sonucuna ulaşılmıştır. Alan yazın incelendiğinde ilköğretim ve ortaöğretim öğretmenleriyle yürütülen çalışmalarda, öğretmenlerin öğrenen özerkliğinin desteklenmesini gerekli buldukları ancak çoğu zaman sergilemedikleri ifade edilmektedir (Kozak, 2017; Oğuz, 2013b; Oğuz, Altınkurt, Yılmaz ve Hatipoğlu, 2014; Özkal ve Demirkol, 2014). Bu araştırmada elde edilen sonuçlar ile belirtilen araştırma sonuçları örtüşmemektedir. Araştırmadan elde edilen bu sonuç beden eğitimi öğretmenlerin öğrenen özerkliğini destekleme davranışlarını gerekli görme ve sergileme davranışlarında tutarsızlıklar olduğu, yapılandırmacı kuram çerçevesinde beden eğitimi öğretmenlerinin öğrenen özerkliğini düşük düzeyde gerekli gördükleri ve düşük düzeyde önemsedikleri şeklinde yorumlanabilir. Ayrıca beden eğitimi öğretmenlerin öğrenci özerkliğini desteklemek için kullanabilecekleri belirleyici stratejiler konusunda yetersiz oldukları (Perlman ve Webster, 2011), yapılandırmacı kurama dayalı programın uygulanması için yeterli bilgiye sahip olmadıkları (Gülüm ve Bilir, 2011) bulgusundan hareketle; sergiledikleri ve gerekli gördükleri özerklik davranışlarının bu nedenlerden dolayı düşük düzeyde olabileceği düşünülmektedir.

Beden eğitimi öğretmenlerin öğrenen özerkliğini destekleme davranışlarının alt boyutları arasında en çok "değerlendirme süreci desteğini" gerekli bulduklarını ve sergilediklerini belirtmişlerdir. Bu boyutu sırası ile gereklilik düzeyinde "öğrenme süreci desteği" ve "duygu ve düşünce desteği" takip ederken; sergileme düzeyinde ise "duygu ve düşünce desteği" ve "öğrenme süreci desteği" takip etmektedir. 
Alan yazın incelendiğinde Kozak (2017), beden eğitimi öğretmenlerinin öğrenen özerkliğini destekleme davranışlarını incelemiş; gereklilik ve sergileme düzeyinde "duygu ve düşünce desteği" alt boyutu ortalamalarının en yüksek olduğu bulgusuna ulaşmıştır. Oğuz ve arkadaşları (2013b) ise, ilkokul, ortaokul ve lise öğretmenlerinin özerklik desteği boyutları arasında en çok duygu ve düşünce desteğini gerekli buldukları ve sergiledikleri sonucuna ulaşmıştır. Yurtseven ve Özaydınlık (2018) da, ortaöğretim öğretmenlerinin öğrenen özerkliğini destekleme davranışlarını gerekli görme ve sergileme düzeyleri ile denetim odağı eğilimlerinin belirlenmesini amaçladığı çalışmasında öğrenen özerkliğini destekleme davranışlarını gerekli görme ve sergileme ölçeğinde "duygu ve düşünce desteği" daha yüksek düzeydeyken, "öğrenme süreci desteği" ve "değerlendirme desteği" boyutları daha düşük düzeydedir. Oğuz (2013b), Oğuz ve arkadaşları (2014) ve Özkal ve Demirkol (2014)'un çalışma bulguları da benzer sonuçlar içermektedir. Bu araştırmadan elde edilen sonuç yukarıda belirtilen araştırma sonuçlarıyla örtüşmemektedir. Bu araştırmadan elde edilen "değerlendirme süreci desteğinin" gerekli bulunması ve sergilenmesi, yapılandırmacı anlayışa göre öğrencinin öğrenme sürecinin merkezinde ve aktif bir rol oynaması gerektiği (Spigner-Littles ve Anderson, 1999) ve ölçme değerlendirme uygulamalarının, diğer unsurlara göre daha merkezi bir öneme sahip olması görüşünden (Biggs, 1999) hareketle önemli görülmektedir. Beden eğitimi öğretmenlerinin öğrencilerin ölçme ve değerlendirme ile ilgili kararlara katımalarını destekledikleri ve öğrencilerin kendi çalışmalarını değerlendirmelerine olanak verdikleri şeklinde yorumlanmaktadır.

Beden eğitimi öğretmenlerinin liderlik stiline ilişkin araştırma sonuçları ise öğretmenlerin "yarı demokratik liderlik stili" sergiledikleri yönündedir. Çelik ve Tamer (2014), Güllü ve Arslan (2009) da beden eğitimi öğretmenlerini dahil ettikleri çalışmalarında beden eğitimi öğretmenlerinin yarı demokratik liderlik stiline sahip oldukları sonucuna ulaşmışlardır. Beden eğitimi öğretmenlerinin öğrencilere karşı otokratik/baskıcı davranış ile demokratik/katıımcı davranış arasında yarı demokratik davranış sergilediği, öğretme sürecine öğrencilerin kararlarına kısıtlı olarak başvurdukları şeklinde yorumlanabilmektedir. Buckner ve Mc Dowelle (2000) da öğretmenlerin okul liderliği çabalarındaki başarılarının sınırı kaldığını belirtmektedir.

Beden eğitimi öğretmenlerin öğrenen özerkliğini destekleme davranışları cinsiyet değişkenine göre farklılık göstermemektedir. Akçil ve Oğuz (2015), Oğuz ve ark. (2014), Yılmaz ve ark. (2017) ve Uşun, Yakar ve Kahya (2016) da yaptıkları çalışmalarda, özerklik destekleme davranışlarının cinsiyete göre değişmediği sonucuna ulaşmışlardır. Er (2014), Oğuz (2013b) ve Özkal ve Demirkol'un (2014) araştırmalarında ise, cinsiyete göre anlamlı farklıık bulunmuştur. Bu bilgilerden hareketle; bazı çalışmalarda öğrenen özerkliği destekleme davranışı cinsiyete göre farklııı gösterirken, bazılarında göstermemektedir.

Aynı zamanda beden eğitimi öğretmenlerin cinsiyetlerine göre liderlik stilleri arasında da anlamlı bir farklılık elde edilmemiş. Seçgel (2005); Hasançebioğlu (2002), Güllü ve Arslan (2009) ve Ercoşkun, Bektaş ve Nalçacı (2009) da araştırmalarında benzer bulgular elde etmişlerdir. Kadın ve erkek beden eğitimi öğretmenlerinin liderlik stillerinin farklılaşmadığı, birbirine benzerlik gösterdiği ifade edilebilir.

Beden eğitimi öğretmenlerinin okul düzeylerine göre öğrenen özerkliğini destekleme davranışları arasında bir fark elde edilmemiştir. Ortaokul ve lise beden eğitimi öğretmenlerinin öğrenen özerliğini destekleme davranışları bu çalışmada benzer bulunmuştur. Oğuz ve arkadaşları (2014), Uşun, Yakar ve Kahya (2016) da öğretmenlerin öğrenen özerkliğini destekleme davranışlarının ortaokul ve lise öğretmenleri arasında farklılaşmadığını belirtmiştir. Aynı zamanda beden eğitimi öğretmenlerinin liderlik stilleri de okul düzeyine göre farklılaşmamaktadır. Ortaokul ve lisede görev yapan beden eğitimi öğretmenlerinin yarı demokratik liderlik stiline sahip oldukları ifade edilmektedir. Güllü ve Arslan'ın (2009), Memişoğlu ve Çakır'ın (2015) ve Seçgel'in (2005) yaptığı araştırmalarda öğretmenlerin liderlik stilleri okul düzeyine göre farklılaşmamaktadır. 
Beden eğitimi öğretmenlerinin sınıf mevcut gruplarına göre öğrenen özerkliğini destekleme davranışlarında anlamlı bir fark elde edilmemiştir. Öğrencilerin derse aktif olarak katıımında ve etkili öğrenmeyi sağlamada önemli bir faktör olan sınıf mevcudu (Şendur, 1999) bu çalışmada beden eğitimi öğretmenlerinin öğrenci özerkliğini gerekli görme ve sergileme davranışlarında farklıık yaratmamıştır.

Aynı zamanda öğretmenlerin liderlik stilleri de sınıf mevcut gruplarına göre farklılaşmamaktadır. Liderlik; öğrencileri yönlendirmek, görevleri devretmek, sınıf etkinliklerini denetlemek, öğrencinin performansını artırmak için stratejiler kullanmak, disiplini sağlamak ve çatışmayı yönetmek gibi rolleri içerdiğinden (Finger ve Bamford, 2010) dolayı sınıf mevcudundan etkilenmektedir (Karabağ Köse, 2018). Sınıf yönetiminde öğretmenin sahip olduğu liderlik stilini etkileyen sınıf mevcudu bu çalışmada farklıık yaratmamıştır.

Yapılan korelasyon analizleri sonucunda beden eğitimi öğretmenlerin öğretmen liderlik stilleri ve öğrenen özerkliğini destekleme davranışları arasında negatif yönlü düşük düzey bir ilişki elde edilmiştir. Öğretmenlerin öğrenci özerkliğini destekleme davranışları arttıkça liderlik stillerine ilişkin puanlarında azalma olduğuna ilişkin bulgu tutarsızdır. Yani liderlik davranışları gösteren öğretmenlerin aynı zamanda öğrencilerin özerklik girişimlerini de desteklediği; öğrencilerin özerkliklerini ancak liderlik davranışları sergileyen öğretmenlerin destekleyebileceği belirtilmektedir (Yılmaz, Oğuz ve Altınkurt, 2017). Aynı zamanda öğretmenin sahip olduğu kolaylaştırıcı liderlik görevinin öğrencilerin kendi yollarını tayin edebilmelerine, kendi kararlarını verebilmelerine olanak sağladığı ifade edilmektedir (Heron, 1999). Özkal (2014) da insancıl sınıf yönetimine sahip öğretmenlerin öğrencilere daha fazla özerklik kazandırmaya yönelik davranışlar sergilediklerini ifade etmiştir.

Mesleki çalışma yılı ve öğrenen özerkliğini destekleme davranışları arasında ise pozitif yönlü düşük düzey anlamlı bir ilişki bulunmaktadır. Öğretmenlerin meslekteki deneyimleri artııça öğrenme özerkliğini destekleme davranışları artmaktadır. Reeve (2009), mesleki çalışma yılı yüksek olan öğretmenlerin öğrenen özerkliği davranışını daha fazla sergilediği görüşündedir. Bu çalışmadaki bulguları (Tablo 7) destekler nitelikte olan diğer bir araştırma da 10-19 yıl ve 20 yıl ve üzerinde kıdeme sahip öğretmenlerin öğrenen özerkliği destekleme davranışlarını 1-9 yıl kıdeme sahip öğretmenlere göre daha fazla sergiledikleri sonucuna ulaşılmıştır (Yılmaz, Oğuz ve Altınkurt, 2017). Bu sonuç, deneyimli beden eğitimi öğretmenlerin var olan deneyimlerini yenilikler için kullandıkları yönünde yorumlanabilir.

\section{Sonuç}

Sonuç olarak, beden eğitimi öğretmenlerinin düşük düzeyde öğrenen özerkliğini gerekli görme ve sergileme davranışlarına sahip oldukları, ayrıca öğrenen özerkliğini gerekli görme ile sergilemeleri arasında da tutarlılık bulunmadığı belirlenmiştir. Beden eğitimi öğretmenlerinin liderlik stillerinden yarı demokratik liderlik stiline sahip oldukları sonucuna ulaşılmıştır. Ancak bu çalışmada beden eğitimi öğretmenlerinin yalnızca öğrenen özerkliğini gerekli görme ve sergilemelerine yönelik görüşlerine ait sonuçların yer aldığı göz önünde bulundurulduğunda, ders uygulamalarında öğrenen özerkliğini sağlamaya ve liderlik stillerine yönelik nasıl davranışlar sergilediklerinin belirlenmesi önerilebilir. Ayrıca beden eğitimi öğretmenlerine öğrenci özerkliğini destekleyici bir sınıf iklimi oluşturmaları için neler yapmaları gerektiğine yönelik hizmet içi eğitim verilmesinin de yararlı olabileceği önerilmektedir. Beden eğitimi öğretmenlerinin öğrenen özerkliğini destekleme davranışlarının gerekliliği ve sergilenmesine ilişkin görüşleri ve öğretmen liderlik stilleri cinsiyet, okul türü ve sınıf mevcut grupları değişkenlerine göre farklılı göstermemiştir. Daha fazla ve farklı bölgeleri içeren 
örneklem grubunun dahil edildiği araştırmaların yapılması bu sonuçların nedenlerinin açıklanması adına önemli görülmekte ve önerilmektedir.

Beden eğitimi öğretmenlerinin öğrenen özerkliğini destekleme ve liderlik stilleri arasında düşük düzeyli negatif ilişki elde edilmiştir. Öğretmenlerin liderlik stilleri ve öğrenciye sağlanan özerklik davranışlarının hem öğretim hem de sosyal roller içeren karmaşık ve çok boyutlu bir süreç olmasından kaynaklı olabileceği (Katyal ve Evers, 2004) bu nedenle de araştırma bulguların nedenlerinin açıklanabilmesi adına nitel araştırma yöntemleri ile desteklenmesi önerilebilir. Bu araştırmanın sınırıı̆̆ı olarak ise, elde edilen sonuçlar öğretmenlerin görüşlerine dayalıdır ve ölçek maddelerini uygun şekilde yanıtladıkları varsayılmaktadır. Örneklem grubu olarak ortaokul ve lise devlet okullarında görev yapan beden eğitimi öğretmenleri dahil edilmiş özel okul öğretmenlerini içermemiştir. Çalışma Mersin iline bağlı ilçelerde yürütülmüş olup diğer illeri kapsamamaktadır. Bu nedenle elde edilen sonuçlar araştırmanın birim evreni için genellenmiştir.

\section{Kaynakça}

Altınkurt, Y. \& Yılmaz, K. (2012). Being a female school administrator in Turkey: Views of teachers and administrators. Energy Education Science and Technology Part B: Social and Educational Studies, 4(4), 2227- 2238.

Akçil M. \& Oğuz A. (2015). Fen Bilgisi Öğretmenlerinin Öz yeterlik İnancı İle Öğrenen Özerkliğini Destekleme Davranışları Arasındaki iliş̧kinin Incelenmesi. Electronic Turkish Studies, 10(11), 1-16.

Angelle, P. S. \& DeHart, C.A. (2011). Teacher perceptions of teacher leadership: examining differences by experience, degree and position. Nass Bulletin, 95(2), 141-160.

Angelle, P. S., Nixon, T. J., Norton, E. M. \& Niles, C. A. (2011). Increasing organizational effectiveness: An examination of teacher leadership, collective efficacy, and trust in schools. Paper presented at the annual meeting of the University Council for Educational Administration, Pittsburgh, PA.

Arat, M. (2001). Değişimin liderleri. Erişim adresi http://www.arguden.net/tr/category/bireysel/degisiminliderleri

Arseven, A. D. (2001). Alan araştırma yöntemi. Ankara: Gündüz Eğitim Yayıncılık.

Arslan, M. (2007). Eğitimde yapılandırmacı yaklaşımlar. Ankara Üniversitesi Eğitim Bilimleri Fakültesi Dergisi, 40(1), 41-61.

Aydın, H. (2006). Eğitimde modern ve postmodern modeller. Bilim ve Gelecek Dergisi. 3, 60-69.

Biggs, J. (1999). Teaching for quality learning at university: What the student does. Open university constructivist approaches in education. Journal of Faculty of Educational Sciences, 40, 41-61.

Black, A. E. \& Deci, E. L. (2000). The effects of instructors' autonomy support and students' autonomous motivation on learning organic chemistry: A self-determination theory perspective. Science Education, 84(6), 740-756.

Brooks, J. G. \& Brooks, M. G. (1993). In Search of Understanding: The Case for Constructivist Classrooms. Alexandria, VA, American Society for Curriculum Development.

Buckner, K. G. \& McDowelle, J. O. (2000). Developing teacher leaders: Providing encouragement, opportunities, and support. NASSP bulletin, 84(616), 35-41.

Can, N. (2009). Öğretmen liderliği. Ankara: Pegem Akademi.

Can, N., Diken, i. H., Demir, S., Güngör, H. C. \& Ardıç, A. (2011). Sınıfta etkili öğretim ve yönetim. Ankara: Data Yayın Dağıım. 
Chiu, H. L. W. (2012). Supporting the development of autonomous learning skills in reading and writing in an independent language learning centre. Studies in Self-Access Learning Journal, 3(3), 266-290.

Çelik, O. B. \& Tamer, K. (2014). Farklı Liderlik Stillerine Sahip Olan Beden Eğitimi Öğretmenlerinin Sınıf Yönetimi Davranışlarının İncelenmesi. Gazi Beden Eğitimi ve Spor Bilimleri Dergisi, 23(2), 85-102.

Deniz, L. \& Hasançebioğlu, T. (2003). Öğretmen liderlik stillerini belirlemeye yönelik bir ölçek çalışması. Marmara Üniversitesi Atatürk Eğitim Fakültesi Eğitim Bilimleri Dergisi, 17(17), 55-62.

Driver, R., Aasoko, H., Leach, J., Mortimer, E. \& Scott, P. (1994). Constructing scientific knowledge in the classroom. Educational Researcher, 23 (7), 5-12.

Ensari, H. (1993). Okul Yöneticilerinin Liderlik Davranışlarının ve Ortamın Öğretmenler Tarafından Değerlendirilmesi. Marmara Üniversitesi Atatürk Eğitim Fakültesi Eğitim Bilimleri Dergisi, 5. 47-51

Er, K. O. (2014). Balıkesir Üniversitesi Necatibey Eğitim Fakültesi İngilizce Öğretmenliği Anabilim Dalı öğrencilerinin öğrenen özerkliği konusundaki görüşleri. Balıkesir University Journal of Social Sciences Institute, 17(31).

Ercoşkun, M.H., Bektaş, F. \& Nalçacı, A. (2009). A Study On Teacher Leadership Styles of Teacher Candidates Studying at The Departments of Secondary Education.

https://core.ac.uk/download/pdf/153447057.pdf adresinden 10.10.2019 tarihinde erişilmiştir.

Finger, J. \& Bamford, B. (2010). Sınıf yönetimi stratejileri öğretmen kılavuzu. (Çev. Ed.Turgut Karaköse). Ankara: Nobel Yayın Dağıtım.

Hasançebioğlu, T. (2002). Öğretmenlerin liderlik stilleri bilgisayar tutumları ve aralarındaki ilişkilerin incelenmesi. Yayınlanmamış Yüksek Lisans Tezi, Marmara Üniversitesi, İstanbul.

Heron, J. (1999). The Complete Facilitator's Handbook. Kogan Page Ltd.

Holec, H. (1991). Autonomie De L'apprenant: De L'enseignement A L'apprentissage. Education Permanente, 107, 1-5.

Hooyman, A., Wulf, G. \& Lewthwaite, R. (2014). Impacts of autonomy-supportive versus controlling instructional language on motor learning. Human Movement Science, 36, 190-198.

Huck, S. W. (2008). Reading statistics and research (5rd edition). New York: Addison Wesley Longman.

Gömleksiz, M. N. \& Bozpolat, E. (2012). Learner autonomy in foreign language learning in elementary school. Journal of World of Turks, 4(3), 95-114.

Greenlee, J. B. (2007). Building teacher leadership capacity through educational leadership programs. Journal of Research for Educational Leaders, 4(1), 44-74.

Güllü, M. \& Arslan, C. (2009). Beden eğitimi öğretmenlerinin liderlik stilleri. Mustafa Kemal Üniversitesi Sosyal Bilimler Enstitüsü Dergisi, 6(11), 353-368.

Gülüm, V. \& Bilir, P. (2011). Beden Eğitimi Öğretim Programının Uygulanabilme Koşulları İle İlgili Beden Eğitimi Öğretmenlerinin Görüşleri. Spormetre Beden Eğitimi ve Spor Bilimleri Dergisi, 9(2), 57-64.

Güvenç, E. \& Güvenç, H. (2014). Illköğretim matematik ile fen ve teknoloji öğretmenlerinin sınıf yönetim biçemleri ve özerklik desteği algıları. NWSA-Education Sciences, 9(3), 311-322.

İlgar, L. (2000). Eğitim Yönetimi, Okul Yönetimi, Sınıf Yönetimi. (2. Basım). İstanbul: Beta Basım.

Karasar, N. (2008). Bilimsel Araştırma Yöntemi. Ankara: Nobel Yayın Dağıtım.

Karabağ Köse, E. (2018). Sınıf Yönetimi. Ayşe Ottekin Demirbolat (Ed.). Değişim Sürecinde Lider Öğretmen Olmak, Pegem Akademi, Ankara.

Katyal, K. R. and Evers, C. W. (2004). Teacher leadership and autonomous student learning: Adjusting to the new realities. International Journal of Educational Research, 41(4-5), 367-382.

Kıranlı, S. (2013). Teachers' and school administrators' perceptions and expectations on teacher leadership. International Journal of Instruction, 6(1), 179-194. 
Koçel, T. (1989). İşletme Yöneticiliği. İstanbul: Beta Yayınevi.

Kozak, M. (2017). Beden Eğitimi Öğretmenlerinin Öğrenen Özerkliğini Destekleme Davranışları İle Mesleki Öz-Yeterlik Algıları, Yayımlanmamış Yüksek Lisans Tezi, Akdeniz Üniversitesi, Sağlık Bilimleri Enstitüsü, Antalya.

Küçüközkan, Y. (2015). Liderlik ve motivasyon teorileri: Kuramsal bir çerçeve. Uluslararası Akademik Yönetim Bilimleri Dergisi, 1(2), 86-115.

Lieberman, A. \& Friedrich, L. (2007). Teachers, writers, leaders. Educational Leadership, 65(1), 42-47.

Maxwell, J.C. (2003). Real leadership: The 101 collection what every leader needs to know. Nashville. TN: Thomas Nelson Inc.

McGregor, D. (1970). Theory X and theory Y. Organization Theory, 358-374.

McGarry, D. (1995). Learner Autonomy 4: The Role of Authentic Texts. Dublin. Authentik.

Memişoğlu, S. P. ve Çakır, M. (2015). Öğretmenlerin liderlik stilleri ile sınıf içi öğretmen davranışları arasındaki ilişkinin incelenmesi. Electronic Turkish Studies, 10, 15.

Millî Eğitim Bakanlığı [MEB] (2006). Beden eğitim öğretmeni özel alan yeterlilikleri. Ankara: Öğretmen Yetiştirme ve Eğitimi Genel Müdürlüğü, 2590 Sayılı Tebliğler Dergisi.

Milli Eğitim Bakanlığı [MEB] (2017). Beden eğitimi ve spor dersi öğretim programı (Ortaokul 5, 6, 7 ve 8. Sınıflar). Ankara.

Moore, K. D. (2001). Classroom teaching skills. New York: Mc Graw Hill

Oğuz, A. (2013a). Öğrenen özerkliğini destekleme ölçeğinin geliştirilmesi. Kuram ve Uygulamada Eğitim Bilimleri, 13(4), 2177-2194.

Oğuz, A. (2013b). Öğretmenlerin öğrenen özerkliğinin desteklenmesini ilişkin görüşleri. International Journal of Human Sciences, 10 (1), 1-26.

Oğuz, A., Altınkurt, Y., Yılmaz, K. \& Hatipoğlu, S. (2014). Öğretmenlerin eğitim inançları ile öğrenen özerkliğini destekleme davranışları arasındaki ilişki. Turkish Journal of Educational Studies, 1(1).

Olsen, D. G. (1999). Constructivist principles of learning and teaching methods. Education, 120 (2), 347-355

Özcan, G. \& Mirzeoğlu, A. D. (2014). Beden eğitimi öğretim programına ilişkin öğrenci, veli ve beden eğitimi öğretmenlerinin görüşleri. Amasya Üniversitesi Eğitim Fakültesi Dergisi, 3(1), 98-121.

Özkal, N. (2014). Sense of professional self-efficacy beliefs and learner autonomy support behaviour of middle school teachers. The Anthropologist, 18(2), 575-581.

Özkal, N. \& Demirkol, A. Y. (2014). Öğrenen özerkliğinin desteklenmesinin gerekliliğine ve sergilenmesine ilişkin öğretmen görüşleri. NWSA-Education Sciences, 9(3), 293-310.

Öztürk, i. H. (2012). Öğretimin planlanmasında öğretmenin rolü ve özerkliği: Ortaöğretim tarih öğretmenlerinin yıllık plan hazırlama ve uygulama örneği. Kuram ve Uygulamada Eğitim Bilimleri, 12(1), 271-299.

Perlman, D. \& Webster, C. A. (2011). Supporting student autonomy in physical education. Journal of Physical Education, Recreation \& Dance, 82(5), 46-49.

Reeve, J. (2009). Why teachers adopt a controlling motivating style toward students and how they can become more autonomy supportive. Educational Psychologist, 44(3), 159-175.

Reeve, J., Bolt, E. \& Cai, Y. (1999). Autonomy supportive teachers: How they teach and motivate students. Journal of Educational Psychology, 91(3), 537-548.

Reeve, J. \& Tseng, C. M. (2011). Cortisol reactivity to a teacher's motivating style: The biology of being controlled versus supporting autonomy. Motivation and Emotion, 35(1), 63-74.

Ryan, R. M. \& Deci, E. L. (2000). Self-determination Theory and the Facilitation of Intrinsic Motivation, Social Development, and Well-Being. American Psychologist, 55 (1), 68-78.

Sanli, E. A., Patterson, J. T., Bray, S. R. \& Lee, T. D. (2013). Understanding self-controlled motor learning protocols through selfdetermination theory. Frontiers in Psychology, 3.

Scharle, A. and Szabo, A. (2000). Learner Autonomy A Guide to developing learner responsibility. United Kingdom, Cambridge University Press. 
Seçgel, N. (2005). Müzik öğretmenlerinin liderlik stilleri. Yayınlanmamıș Yüksek Lisans Tezi. İstanbul: Marmara Üniversitesi.

Sierens, E., Vansteenkiste, M., Goossens, L., Soenens B. \& Dochy, F. (2009). The synergistic relationship of perceived autonomy support and structure in the prediction of self-regulated learning. British Journal of Educational Psychology, 79, 57-68.

Spigner-Littles, D. \& Anderson, C. E. (1999). Constructivism: A Paradigm for Older Learners. Educational Gerontology, 25(3), 203-209.

Şendur, E. P. (1999). Sınıf atmosferi ve öğrenci güdüsü. Yüksek Lisans Tezi, Dokuz Eylül Üniversitesi, İzmir.

Topkaya, i. (2007). Hareket, beden eğitimi ve spor öğretiminde öğrenme ve öğretimin temelleri. Nobel Yayınları, Ankara.

Tevruz, S., Artan, İ. \& Bozkurt, T. (1999). Davranışlarımızdan seçmeler (örgütsel yaklaşım). İstanbul: Beta Basım Yayın Dağıtım.

Uşun S., Yakar A. \& Kahya O. (2017) Sınıf öğretmenlerinin ve ortaokul branş öğretmenlerinin öğrenen özerkliğini destekleme davranışlarının incelenmesi. Cumhuriyet International Journal of Education, 5: 72-81

Üstünoğlu, E. (2009). Dil öğrenmede özerklik: Öğrenciler kendi öğrenme sorumluluklarını üstlenebiliyorlar mı?. Egitimde Kuram ve Uygulama, 5(2), 148-169.

Yager, R. E. (1991). The constructivist learning model towards real reform in science education. The Science Teacher National Science Teachers Association, 58 (6), 52-57.

Yılmaz, K., Oğuz, A. \& Altınkurt, Y. (2017). Öğretmenlerin liderlik davranışları ile öğrenen özerkliğini destekleme davranışları arasındaki ilişki. Hacettepe Üniversitesi Eğitim Fakültesi Dergisi, 32(3), 659-675.

Yiğit, Y., Doğan, S. \& Uğurlu, C. T. (2013). Öğretmenlerin öğretmen liderliği davranışlarına ilişkin görüşleri. Cumhuriyet International Journal of Education, 2(2), 93-105.

Yurtseven, G. Ö. \& Özaydınlık, K. B. (2018). Ortaöğretim öğretmenlerinin öğrenen özerkliğini destekleme davranışları ve denetim odağı eğilimleri. illköğretim Online, 17(4).

Wang, P. (2011). Constructivism and learner autonomy in foreign language teaching and learning: To what extent does theory inform practice?. Theory and Practice in Language Studies, 1(3), 273-277.

Wulf, G., Chiviacowsky, S. \& Cardozo, P. L. (2014). Additive benefits of autonomy support and enhanced expectancies for motor learning. Human Movement Science, 37, 12-20.

Wulf, G., Chiviacowsky, S. \& Drews, R. (2015). External focus and autonomy support: two important factors in motor learning have additive benefits. Human Movement Science, 40, 176-184.

Wulf, G., Freitas, H. E. \& Tandy, R. D. (2014). Choosing to exercise more: Small choices increase exercise engagement. Psychology of Sport and Exercise, 15, 268-271. 